\title{
CD97 Antigen
}

National Cancer Institute

\section{Source}

National Cancer Institute. CD97 Antigen. NCI Thesaurus. Code C25798.

CD97 antigen (835 aa, $\sim 92 \mathrm{kDa}$ ) is encoded by the human ADGRE5 gene. This protein plays a role in G protein-coupled receptor signaling, cell adhesion and leukocyte migration. 